\title{
The main threats to economic security of the country
}

\author{
Yuliya Bystrova ${ }^{1 *}$, Sergei Melnik ${ }^{2}$, Pavel Nadtachaev ${ }^{3}$,Bela Bidova ${ }^{4}$, and Gennadii \\ Pratsko ${ }^{5}$ \\ ${ }^{1}$ Orel State University named after I. S. Turgenev, 95 Komsomolskaya str., Orel, 302028, Russia \\ ${ }^{2}$ Orel Law Institute of the Ministry of Internal Affairs of Russia named after V. V. Lukyanov, 2 \\ Ignatova str., Orel, 302027, Russia \\ ${ }^{3} \mathrm{Ufa}$ Law Institute of the Ministry of Internal Affairs of Russia, 2 Muksinova str., Orel, 450130, \\ Russia \\ ${ }^{4}$ Chechen State University, 32 Sheripova str., Grozny, 364093, Russia \\ ${ }^{5}$ Don State Technical University, 1 Gagarin str., Rostov-on-Don, 344000, Russia
}

\begin{abstract}
At present, in the period of complicated international legal relations, there is an intensive need for ensuring economic security of our country. It is the economic sphere that is the ground for internal policy of the government, the human factors system of every citizen and society as a whole. As the main threats to economic security of our country, suboptimal public administration and a high level of criminalization and corruption in the economic sphere should be identified. In this article, the mentioned threats are considered as the main ones, based on the represented statistical data on the character of damage caused to economy of our country. Criminalization of the management sphere is widening every year, the percentage of official crimes committed is inexorably rising. The amount of embezzlement of budget funds committed by persons whose official duties are directed at protecting the national interests and performing basic governmental objectives, is also staggering. A large enough volume of legal acts directed at regulating management processes and narrowing the "sector for abuse" is adopted annually, however, the number of offenses does not reduce. In this connection, we propose to change the approach to measures of legal liability for committed deeds.
\end{abstract}

\section{Introduction}

At present time, the threats of destabilizing the world market by crisis phenomena complicated by the processes of globalization are increasing. An effective system of economic security is the cornerstone to successful development of any society and economy. Sharp spikes in exchange rates, financial sector and the raw materials market instability, emerging new types of fraud in the banking sector - all these challenges necessitate developing new parameters for economic security of the country. Besides, the pandemic of the new coronavirus infection has influenced greatly the socio-economic

\footnotetext{
*Corresponding author: zukova57@mail.ru
} 
sphere of interests of both ours and foreign countries. It will take quite a long time for even the world's major economies to overcome the consequences of this coronavirus pandemic. The reason for this is that, first of all, the countries were not ready for the "introducing restrictive measures" period, since neither the economic nor legal sphere have yet encountered a similar situation. As known, taking decisions "on the situation" has a negative impact on the long-term development of one or another block. At the expense of significant budget injections, it became possible to "keep afloat" the small and mediumsized business sector, provide situational assistance to citizens, and reduce the burden of expenses incurred by system-forming enterprises. However, instability and uncertainty of the prospects for the global economy development, which have been observed over the last years, have significantly increased. Significant threats to economic security of Russia are being formed in connection with the high risk of expanding sanctions pressure both directly on Russian companies and on their foreign partners, primarily in the oil and gas industry, machinery manufacturing, and information and telecommunications spheres. However, the introduction of measures directed at countering the new coronavirus infection has caused digital technologies and digital economy development, which are becoming the determining factors of high competitiveness in the modern world.

The COVID-19 pandemic also has clearly identified new operational requirements for the sectors that directly determine human living conditions - health and education, working and leisure conditions, and the motivation system [1]. Studying, in the current world situation, the ways of preventing threats to economic security and stabilizing the economic situation, one should hold the position that it is necessary first of all to create an effective management unit. So, after past crises, understanding the role of corporate governance to strengthen financial stability is growing. Besides, corporate management issues, such as top management compensation, board of directors' composition and directors' independence, agency theory or proper evaluation, are issues that need to be analyzed when assessing how they affect financial stability [2]. The problems of finding ways to stabilize economic situation and prevent threats to economic security are not new, and there are quite a lot of studies in this sphere both among the domestic and foreign scientific community. In particular, these are first of all the works of B. Fischhoff, S. Watson [3], W. Hudson [4], H. Willet Allan [5], L. von Bertalanfi [6], Walter Isard, Dick C. Nanto [7], F. Andrew, and J. R. R. Tolkien. Krepinevich [8], K. Murdoch [9], W. Hager [10], et al.

The purpose of this work is analyzing the threats to economic security of the country that have an impact on effective public administration and create high level of criminalization and corruption in the economic sphere, and also making proposals for current legislation reformation in order to prevent the negative trends mentioned.

\section{Materials and methods}

For the purpose of writing this article, various methods were used. The dialectical method of cognition allowed identifying basic laws and categories of economic security from the perspective of science, and also the socio-economic roots of threats to economic security of the country. Practical character of the dialectical method involves applicating dialectics categories in the implementation of criminal law norms in court and investigative practice.

When writing the article, the specific scientific methods were also used. The logicallegal method was used for disclosure of economic security concept and essence, and also its threats and principles. The comparative-legal method was used as the basis for analysis of individual socio-legal institutions, categories and concepts by comparing them with similar foreign countries' legislation provisions. The methods of analysis and synthesis were used to summarize theoretical and practical material and form the conclusions based on them. The statistical and sociological methods allowed analyzing the consequences of the current 
negative socio-economic situation. These methods allowed considering the essence of economic security not only from a scientific, but also from a practical point of view, finding out the characteristics of its threats, and formulating the ways to prevent them.

\section{Results and discussion}

Actuality of the chosen topic is determined by increasing percentage of economic crimes committed, and also by continuing growth of corruption at all levels of governance (Fig.1). The modern mechanism for ensuring economic security must constantly transform along with the emerging new risks and threats in the economic sector of the country. Obviously, in the modern period, economic security in foreign trade, business security and international economic security are put to the forefront. It is necessary to improve the mechanism for ensuring economic security of the Russian Federation in respect to new economic risks, both at the federal and regional levels. Further international cooperation in the sphere of ensuring economic security and development of universal international legal norms in this direction are needed. Information technologies are also used to commit crimes that trespass on intellectual property, constitutional rights and freedoms of citizens, economic and public interests. In practice, it became necessary to work with increasing number and types of crimes in the sphere of computer information, identifying the elements, clarify the objective side of the elements of existing crimes, and differentiate the responsibility of the guilty persons. Research in the field of computer crimes is necessary to improve national security, in whole, and to increase the security level in corporate and individual information systems, in part. Rapid development of new technologies and their active implementation into the daily life $[10,11]$ assign new objectives to Law.

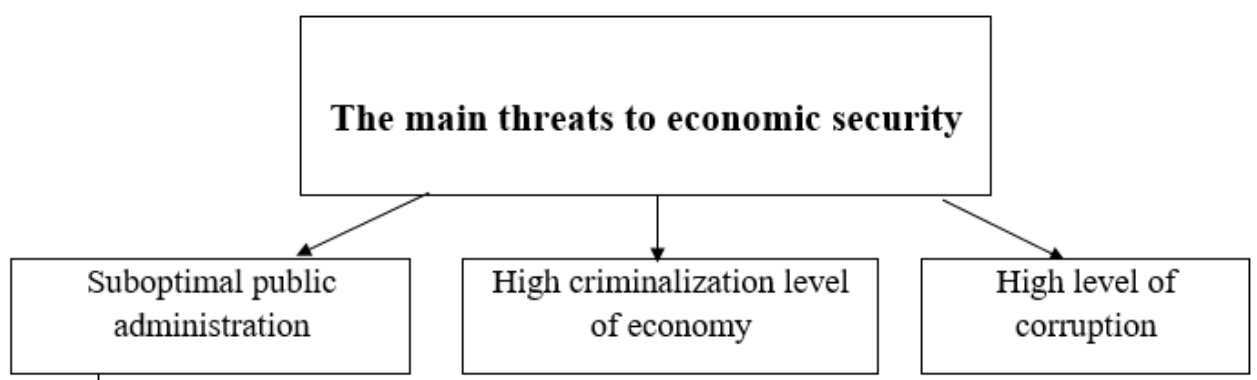

Fig. 1. The main threats to economic security.

The main directions of improving the mechanism for ensuring the economic security of the Russian Federation in the modern period, first of all, concern the sphere of high technologies. It is its development that will allow securing the industrial sector. Sanction measures against the Russian Federation prioritize the problem of overcoming dependence on imported equipment in industrial spheres. Efficient use of budget funds and reducing debt dependence also occupy rather a significant place in the complex of measures to ensure economic security of our country.

The main objective of the economic strategy is restoring the necessary pace of economic growth for Russia to emerge from the global crisis.

According the Strategy of Economic Security of the Russian Federation for the period up to 2030, the term "economic security" is defined as "the position of national economy protection from external and internal threats, which ensures economic sovereignty of the country, unity of its economic space, and conditions for implementing strategic national priorities of the Russian Federation" [12]. 
Considering the term "economic security", the question of what constitutes "economic insecurity" is quite reasonable. It should be noted that this term is not used in the existing legislation, however, the term "threat to economic security" is actively used. It is possible to formulate a definition of economic insecurity based on the meaning of the word "insecurity" itself. Nevertheless, we can also offer the following definition. Economic insecurity is the possibility of a negative impact on the object of ensuring economic security, as a result of which this object may be damaged, as well as economy of the country as a whole. The insecurity can usually be of a probabilistic or causal nature and it serves as the basis for exploring the problems of economic security.

The foregoing allows stating with confidence that economic security is the position of national economy protection from external and internal threats, which ensures economic sovereignty of the country, unity of its economic space, and conditions for implementing strategic national priorities of the Russian Federation.

While appealing to the abovementioned objectives, we note that ensuring economic security of the Russian Federation is a legally established activity of governmental and nongovernmental bodies and structures, the purpose of which is maintaining economic sovereignty, ensuring stability of Russian economy, and also counteracting internal and external threats in this area. In order to implement an efficient market policy, it is necessary to have an appropriate governmental mechanism in place to maintain economic security of Russia. And it is, first of all, an effective management sphere. It is the managerial sphere that is entrusted on behalf of the government with the duties of daily ensuring not only economic, but also national security in whole, through the efficient and proper performance of their official duties, and also the implementation of social programs to support the population, the development of world trade, the maintenance of defense capabilities, etc.

Over the last years, the main direction of the national policy, and as a result, the vector of legislative activity, is reforming the budget system, in order to determine the optimal mechanism for satisfying public needs at the expense of budget funds. Based on the definition of this direction, it can be stated that a sufficiently large amount of budget funds is provided to meet public needs.

Therewith, the Accounts (Audit) Chamber of the Russian Federation in 2020 [13] revealed 3.7 thousand abuses in the budgetary sphere for a total of 355.5 billion rubles. Of these, 16.423 billion rubles were returned to the budget. Therewith, in 2019, the auditors found 4.4 thousand abuses for 884.6 billion rubles, however the return of funds to the budget system was provided for a significantly smaller amount -4.516 billion rubles.

As a whole, in 2020, the increase in crimes in the public sphere was $11 \%$ compared to 2019.

When analyzing the presented figures, it should be stated that the management sphere "failed" to solve the objectives assigned to it. As a result of improper performance of the assigned duties by managers, not only material loss to the country was caused, but also economic security was endamaged. As a rule, abuses in the budget sphere are first of all associated with untargeted and inefficient spending of budget funds. In the performance of the assigned duties directed at implementation of a certain function of the government, the official - manager is guided not by interests of the nation, but by personal ones. Despite the fact that the illegal actions of such persons are detected, the abuses committed are stopped, however, this, unfortunately, is not an efficient barrier to committing these criminal acts. In this case, the question of sufficiency of the governmental enforcement measures applied in the budget sphere is quite reasonable. Below, we review the examples of court practice on typical illegal deeds of managers/officers with budget funds and the responsibility measures applied to them.

Untargeted use of budget funds, which is, directing the funds of the budget system of the Russian Federation and paying monetary commitments for purposes that do not fully or 
partially meet the purposes determined by the budget act (or decision), consolidated budget list, budget list, budget computation, contract (agreement) or other document that is the legal basis for provision of these funds, or directing funds received from the budget system of the Russian Federation for purposes that do not meet the purposes defined by the contract (agreement) or other document, which is the legal basis for the provision of these funds. As an example, we can submit a case from the court practice. By the resolution of the Deputy head of the Governor and Government Administration of Orlovskaya oblast (Orel region) A.V. V. of October 8, 2019, the chief physician of the budget health care institution of Orel region Polyclinic No. 2, N.V. Petina, was held administrative liable under Article 15.14 of Administrative Code of the Russian Federation (untargeted use of Budget funds), and she was imposed an administrative fine in the amount of 20,000 rubles. The reason for holding her administratively liable was compulsory medical insurance funds untargeted use when paying the amount of 18,699 rubles 98 kopecks for Alvanak M (hepatitis A vaccine), which is included in the calendar of preventive vaccinations for epidemic indications (these expenses are not included into the structure of the compulsory medical insurance tariff and are budget commitments). Not agreeing with the specified resolution, N. V. Petina filed a lawsuit against it. She asked to cancel the resolution and stop the proceedings initiated against her on an administrative offense, since she committed the administrative offense she was accused of due to extreme necessity, since she was forced to purchase the Algavak $M$ vaccine at the expense of compulsory medical insurance funds due to an outbreak of hepatitis A registered in Sovetsky district of the city of Orel and the need for urgent vaccination of sixteen people. When considering the case, the court came to the conclusion that the amount of funds spent in an inappropriate way was not significant, and those funds were returned to the territorial fund of compulsory medical insurance before initiating the case on an administrative offense. It was also taken into account that the untargeted use of funds was caused by an objectively existing situation related to the registration of a case of acute viral hepatitis A. Also, it was taken into account, that the funds available to the polyclinic during that period from other incomegenerating activities were not spent due to the preservation of social benefits for employees. By the decision of the Soviet District Court of the city of Orel dated December 13, 2019, the resolution of the Deputy Head of the Governor and the Government Administration of Orel Region of October 8, 2019, on holding administrative liable N. V. Petina, who held the position of the chief physician of the budget health care institution of Orel region "Polyclinic No. 2", in the case of an administrative offense under Article 15.14 of the Administrative Code of the Russian Federation, was canceled. The matter was dismissed on the basis of paragraph 3 Part 1 Article 30.7 of the Administrative Code of the Russian Federation. N. V. Petina was discharged from administrative liability due to insignificance of the administrative offense. And there are a lot of such legal disputes.

However, in court practice, there are facts witnessing of various approaches to interpret the deeds of public officers associated with disbursing budget funds. For example, the Orel regional Court considered on appeal the case against two officials of the city: the head of the administration of the city of Orel, U. A. I., and the head of the financial body of Administration of the city of Orel, M. A. V. It was found that as a result of guilty actions of the defendants, that consisted in improper performance of their duties for execution of the budget of the city of Orel, namely, replenishing its revenue part, resulted in loss for the budget of the municipality "City of Oryol". In this connection, the prosecutor of the involved district, acting in interests of the municipality, asked the court to extract the funds by way of recourse in solidarity in favor of the municipality "City of Orel" in the amount of $5,085,761.15$ rubles. This amount of loss(damage) resulted by the reason of negligent performance of their official duties by the defendants and non-applicating the penalties(fines) under the municipal contracts. The court proved the possibility of collecting 
penalties, however, no evidence was presented to confirm the illegal actions of the head of the administration of the city of Orel and the head of the financial Department of the administration of the city of Orel in performing the conditions of municipal contracts by the administration of the city of Orel and the presence of a cause-and effect relationship between their actions and the money collected by court decisions. However, in this case, there is a reasonable question why the investigative authorities did not apply a different type of legal liability to these persons. Appealing to which regulatory acts the supervisory authorities considered it possible to restore the rights of mentioned persons, only by applying civil liability measures, bypassing other types of legal liability.

Besides the obvious abuse of budget funds, a huge niche is occupied by corruption crimes. Corruption is a specific internal threat to economic security. And the extent it has reached in our country is simply shocking. The subject of embezzlement, as a rule, is the budget funds in significant amounts. For example, the Zavodsky District Court sentenced B. D. A., part 1 of art. 285 of the Criminal Code of the Russian Federation, on the fact that being an official - head of a budgetary institution, in order to fulfill governmental powers directed at providing the region with infrastructure for the purpose of developing sports achievements, namely, performing works on reconstruction of the Central Stadium named after V. I. Lenin, he concluded a government contract. However, during the execution of the contract, using his official powers, contrary to the interests of the service, knowing that the planned reconstruction work was not completed in full, he signed the acts of completed work. This resulted in property loss to the Orel region totaling more than 4 million rubles, and also in inability to fully operate the specified sports facility.

And this court litigation is not a single one. There can be seen amounts of damage caused several times higher. For example, on March 4, 2021, the Orel Regional Court [14] changed the measure of restriction against the department deputy head of the KU OO (Public establishment of Orlovskaya oblast/Orel region) "Orelgoszakazchik" A. I. Aleshin from placement in detention to home arrest. Bodies of pretrial investigation accused A. I. Aleshin of exceeding official powers, causing serious consequences (paragraph $\mathrm{B}(\mathrm{v})$ Part 3 Article 286 of the Criminal Code of the Russian Federation).

A. I. Aleshin is accused of that being an official, construction control department chief specialist, of the KU OO "Orelgoszakazchik", responsible for conducting construction control over the performance of works under the municipal contract for construction of the object "The football field with artificial turf " in the township Znamenka, committed actions that clearly exceeded his authority, related to the control over the construction works execution. As a result, the contractor Promekologiya OOO (i.e., an LLC) laid the angular stone, which using is unacceptable at sports facilities. As a result of these actions, according to the investigation, significant material damage was caused to the budget of Orel region in the amount of $12,382,300$ rubles, since the sports facility could not be assumed into municipal ownership. The investigation of this case continues and despite the fact that the investigation bodies are still establishing the circle of officials guilty of committing this corruption crime, however, the damage to the interests of the municipality has been caused by these actions.

For committing illegal actions that cause damage to public entities, officials take bribes.

On February 7, 2020, the Zavodsky District Court of the city of Orel [15] announced a guilty verdict against Ch. V. A., convicted under item “в” (" v ") Part 5 Article 290 of the Criminal Code of the Russian Federation. This person was not head of the organization, but chief specialist, whose official duties included construction control, i.e., monitoring compliance with construction norms and rules. These skills were necessary for him for the purpose of signing the acceptance certificate of the object after the performing the construction works. His duties included acceptance of the work performed on capital construction objects. 
In September 2018, a number of contracts of performing works for government needs were signed with KU OO "Orelgoszakazchik". The essence of the construction works performed consisted in feldsher - midwifery stations construction. The essence of the criminal deed of the guilty person was that during the internal work, the equipment necessary to operate the feldsher station was replaced with a less expensive one and for a bribe of two hundred thousand rubles, Ch.V. A. did not make changes to the project, but accepted it in this form. Given that budget funds were provided for the implementation of these works, a loss was caused to the public entity. For this crime, the penalty was imposed in the form of imprisonment for a period of 7 years of strict regime and a fine of 2,000,000 rubles.

On March 3, 2020, the Zavodsky District Court of the city of Orel announced the guilty verdict against Porchesku, convicted under paragraph "б “("b ") Part 3 Article 291.1 of the Criminal Code of the Russian Federation.

In September 2018, between KU OO Orelgoszakazchik and Industrial Expertise Technical Center OOO (LLC) was signed a contract of performing works for public needs. In April 2019, Porcescu, as an intermediary, delivered 200,000 rubles to the chief specialist of KU OO "Orelgoszakazchik", for the illegal actions committed by him.

The court, having examined the evidence on the matter collected taken together, found Porchesku guilty of directly giving a bribe on behalf of the bribegiver, on a grand scale. The court sentenced Porchesku to a fine of one million rubles.

Thus, in fact, by reason of criminal interaction of these two persons, property damage was caused to the public entity and its economic interests, since a certain amount of money was planned for the construction work, and the construction of these objects was conditioned by the execution of governmental powers. However, due to the criminal interaction, the public entity not only lost a certain amount of money for the work performed "with a defect", but also did not fully fulfill its public commitments, since the constructed object did not fully perform the declared functions.

When we analyze the presented court decrees, the question arises on the law enforcement agencies' approach to the type of legal liability applied in each specific case. Why is it when the chief specialist of a budget institution fails to perform his duties, a criminal case is initiated, as mentioned above, and when the head of the administration fails to perform his duties, only civil liability measures are taken?

In the sphere of countering internal and external threats to economic security, the bodies of all branches of government power, respectively, legislative, executive and judicial, are involved.

The process of ensuring economic security of Russia is directly related to the processes which take place on the world market. Efficient provision of economic security is a guarantee of maintaining economic sovereignty of the country, stability of economic relations within it, and protecting the basic socio-economic rights of the population. For this reason, ensuring economic security is one of the important directions of the governmental economic policy. The main problem remains forecasting, identifying and preventing internal and external threats and challenges to domestic economy. In conditions of modern economic relations, in presence of sanctions and restrictions in connection with the conducted foreign policy, the issue of maintaining economic security of the country comes to the fore. Thus, stability of economy and its growth are the main indicators to assess the economic security condition. In this connection, it is necessary to take measures to provide scientific and technical support to economy of the country.

To the circle of objectives related to the sphere of ensuring economic security, the following can be included:

1) priority of developing and implementing high technologies in the industrial sector and robotization of industrial processes; 
2) development of import substitution;

3) introduction of "mirror" (tit-for-tat) restrictive measures in response to the US sanction pressure;

4) strengthening governmental control over budget expenditures;

5) ensuring stability of the domestic monetary system;

6) intergovernmental and interregional cooperation on issues of global economic integration, etc.

The main directions of improving the mechanism for ensuring economic security of the Russian Federation at the present stage will affect the following areas of activity: ensuring Russian economic interests in foreign trade relations in the context of integration into the world economy; expanding domestic competitive high-tech production, especially in the consumer goods manufacturing and heavy equipment industry sectors; maintaining stable positions in the global commodity and financial market; implementing a policy of protectionism in relation to domestic producers in domestic and foreign markets; taking government measures to reduce external debt of Russia; supporting stability of the national currency; maintaining uninterrupted operation of communication means, and generally all types of communication/transport (road, sea, railway, etc.).

Analyzing the objectives allotted, and also the main directions of ensuring economic security, it should be stated that they have an economic bias and are achieved through use of legal means. However, at the governmental level, it is necessary to work out and entrench, as one of the ensuring economic security directions, taking a range of measures directed at countering corruption in the managerial sphere and at strict suppressing official crimes. Wherein, it is necessary to develop a unified system of legal responsibility measures for these abuses.

The main objective of the economic strategy is restoring the necessary pace of economic growth for Russia to emerge from the global crisis.

\section{Conclusion}

Thus, the key tasks of ensuring economic security should include such as: developing measures to support the national economy during the crisis period; creating organizational conditions for employment; creating economic conditions to reduce inflation and depreciation of the national currency; monitoring the stock market in order to prevent illegal speculation and artificial price inflations; developing measures directed at reducing the budget deficit; adopting an economic strategy to reduce the central government debt of the Russian Federation; improving the level of social and economic security of Russian citizens; forecasting the development of events in the international economic arena for the purpose of identifying negative consequences for national economy of the Russian Federation. In addition to measures directed at ensuring economic security within the country, it is necessary to take measures on the part of the entire world community directed at organizing a system of an international economic security (in the universal and regional sense).

Analyzing the normative provisions and scientific views in part of the main economic security characteristics of the country, it should be stated that internal threats to economic security depend on the management sphere of the country. Namely, the criminalization of the management sphere is a significant threat. It is about the mass committing crimes by employees related to abuse of official powers, bribes and fraud while performing official duties, etc.

It can be stated that at present moment the legislator has settled in sufficient detail the issues of law enforcement and of bringing to legal liability for offenses in the budget sphere. However, there is practically lack of proper control over this area. Very often for 
offenses in this sphere, a guilty person is brought to disciplinary liability, and not to criminal one. And given the amount of budget funds spent in this spere, it is easier for an official to pay a fine and make a sufficient profit from infringing the procedure prescribed by law. In this connection, it is necessary to review the approach of investigative and judicial authorities to the types of legal liability applied in each specific case. We consider it is necessary to apply a unified approach in relation to choosing the type of responsibility for this type of crime. Given that committing these criminal deeds endamages economic interests of public entities, and therefore represents a threat to economic security of the country as a whole, the only type of liability that law enforcement authorities should apply is criminal one.

It seems appropriate to introduce criminal law measures to improve cybercrime prevention. Activities to prevent crimes in the sphere of computer information should be carried out in accordance with a comprehensive approach, namely, combining organizational, managerial, technical and legal measures.

On the ground of the abovementioned, stating the fact of a high administrative and civil liability percentage, a low percentage of criminal one in the budgetary sphere, and also the court practice, which is rich in non-guilty verdicts, we consider it is necessary to strengthen the sanctions for crimes in this sphere and authorize procuracy authorities to initiate court processes of criminal prosecution, rather than for holding guilty persons administrative liable.

\section{References}

1. I. Egorov, Russian Gazette, 152(8206) (2020)

I. Lupu, Procedia Economics and Finance, 22, 538-543 (2015)

2. B. Fischhoff, S. Watson, C. Hope, Policy Sciences, 17, 123-139 (1984)

3. W. Hudson, Economic Security for All: How to End Poverty in the United States (2021), URL: http://shults.org/wadehudson/esfa/

4. A. H. Willett, The economic theory of risk and insurance (University of Pennsylvania Press, 1951)

5. L. Von Bertalanffy, General System Theory (New York, 1968)

6. Economics and National Security: Issues and Implications for U.S. Policy (2011)

7. A. F. Krepinevich, National Security Strategy in an Era of Growing Challenges and Resource Constraints (Washington, 2010)

8. C. Murdoch, Economics issuies \& national security (Lawrence, 2012)

9. S. Makarov, E. Ugnich, Foresight Russia, 9(1), 56-67 (2015)

10. E. Ugnich, A. Chernokozov, M. Ugnich, E3S Web of Conferences, 258, 07053 (2021), DOI: https://doi.org/10.1051/e3sconf/202125807053

11. Decree of the President of the Russian Federation, 208 (2017)

12. The Accounts Chamber of the Russian Federation has provided a return to the budget system of 16.4 billion rubles in 2020 (finam.ru), (2020)

13. The Oryol regional Court changed the measure of restriction against the department deputy head of KU OO "Orelgoszakazchik" from placement in detention to home arrest (2021),

URL: http://oblsud.orl.sudrf.ru/modules.php?name=press_dep\&op=1\&did=1441. 
14. An employee of KU OO "Orelgoszakazchik" was convicted for receiving a grand-scale bribe by an official (2020), URL: http://zavodskoy.orl.sudrf.ru/modules.php?name=press_dep\&op=1\&did=416 